\title{
Intention to Practice Exclusive Breastfeeding and its Associated Factors among Female College Students
}

\author{
Kusuma Estu Werdani ${ }^{1 *}$ (D), Izzatul Arifah ${ }^{1}$, Tanjung Anitasari Indah Kusumaningrum ${ }^{1}$, Anggi Putri Aria Gita ${ }^{2}$, Suci Ramadhani $^{1}$, \\ Aulia Nimas Rahajeng \\ ${ }^{1}$ Department of Public Health, Faculty of Health Science, Universitas Muhammadiyah Surakarta, Surakarta, Central Java, \\ Indonesia; ${ }^{2}$ Department of Health Administration, Faculty of Health Science, Universitas Kusuma Husada Surakarta, Surakarta, \\ Central Java, Indonesia
}

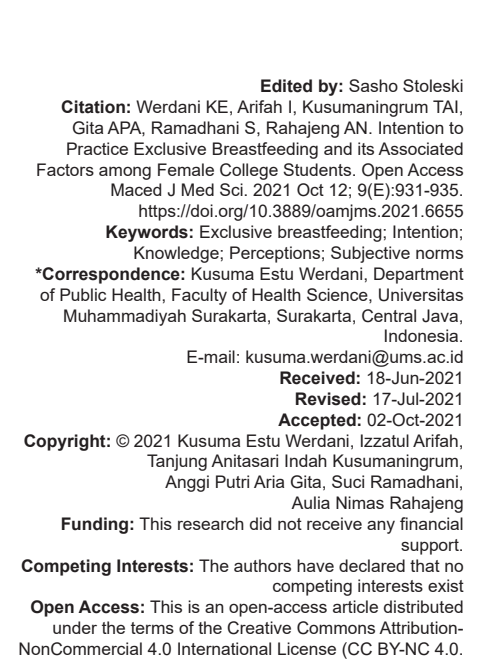

Introduction

Exclusive breastfeeding is one of the efforts to implement balanced nutrition that is applied in Indonesia. This is explicitly stipulated in the policy of the Minister of Health Regulation Number 23 of 2014 concerning efforts to improve nutrition. Government Regulation No. 33 of 2012 also confirms that exclusive breastfeeding is given directly to babies from birth to 6 months of age without adding and or replacing with other foods or drinks, except drugs, vitamins, and minerals. This is because breast milk is believed to contain colostrum which is rich in protein for endurance and reduces the risk of infant mortality. Early initiation of breastfeeding can also facilitate the breastfeeding process, which begins with skin touching between the baby and the mother's chest for at least $1 \mathrm{~h}$ postpartum. Indonesia's coverage of exclusive breastfeeding in 2019 has exceeded the target of the national strategic intention (50\%) which is $67.74 \%$. Likewise, the percentage of babies who were given early initiation of breastfeeding also exceeded the strategic intention target $(50 \%)$ which was $75.58 \%$ [1]. Even though it has exceeded the target, various studies still show the need for attention to the factors that influence exclusive breastfeeding in the community. Occupation, region, and early initiation of breastfeeding are significant factors that predict exclusive breastfeeding. This has an impact on the need for health promotion activities that include the benefits of exclusive breastfeeding and education on appropriate nutrition during pregnancy and postpartum [2]. Preparation for breastfeeding for women needs to start from their teens. Teenage mothers tend to wean their babies more quickly due to difficulty breastfeeding in the first days postpartum and since being discharged from the hospital [3]. The readiness of this adolescent mother is the basis for the formation of breastfeeding attitudes which is a factor in the sustainability of exclusive breastfeeding at four weeks postpartum [4]. Some of the obstacles commonly encountered by postpartum mothers are insufficient 
breastfeeding syndrome, high maternal workload, lack of social support, the role of important people around them, and the proliferation of formula milk promotion strategies [5].

Public health workers have a strategic role in changing people's behavior to support the achievement of clean and healthy living behaviors, including exclusive breastfeeding coverage [6]. This study involved female students of the Public Health Study Program, Faculty of Health Sciences, University of Muhammadiyah Surakarta. This study aims to measure breastfeeding plans to them using the Planned Behavior Theory and Health Belief Model. An intention for exclusive breastfeeding was shown to be influenced by, subjective norms, knowledge, perceived benefit, cost, and vulnerability. Meanwhile, behavioral intentions and perceptions are direct determinants of exclusive breastfeeding behavior [7]. Female public health students will have a dual role in the future, namely, as prospective breastfeeding mothers and health educators in the community. This research contributes more deeply to the factors that may influence their intention to exclusively breastfeed when they become mothers later. Therefore, basic exploration of the relationship between knowledge, subjective norms, and perceptions (benefits, barriers, and vulnerabilities) with exclusive breastfeeding intention in this group is important.

\section{Methods}

\section{Study setting}

This study used an analytical observational design with a cross-sectional approach. This study aims to analyze the relationship between the determinant factors (age, semester level, knowledge, subjective norms, perceived barriers, perceived benefits, and perceived vulnerability) with the intention of exclusive breastfeeding for students of the Public Health Study Program, Faculty of Health, Universitas Muhammadiyah Surakarta.

\section{Sampling strategy}

Considerations for the selection of public health students include (a) as prospective mothers who need preparation to breastfeed their babies and (b) as a prospective health educator who will become a role model in the practice of exclusive breastfeeding. The population in this study were all female students of the Public Health Study Program, Faculty of Health, Universitas Muhammadiyah Surakarta with the status of the semester I, III, V, and VII totaling 504 people. The formula for the proportion of a single population is used to determine the sample size with the following assumptions: $p$ (the proportion of exclusive breastfeeding is $67.74 \%$ based on national data), $d$ (margin of error $=5 \%$ ) and $Z \alpha / 2$ (standard score value for the 95 confidence level) $\%=1.96$ ), the minimum sample size $(n)$ is 187 taking into account the nonresponse rate of $10 \%$.

The sampling technique used is proportional random sampling method with the distribution of each semester as follows: 47 first semester students, 49 third semester students, 47 fifth semester students, and 44 seventh semester students. The exclusion criteria set were respondents who were married.

\section{Data collection}

Data were collected online by distributing links of online questionnaires through social media of selected respondents. Previously, the questionnaires was tested on $10 \%$ of the same source population other than the sample population. Based on the pretest, the questions were revised and edited for participants' clarity and understanding. Finally, the final version of the questionnaire was used for data collection.

\section{Data analysis}

The independent variables in this study consisted of age, semester level, knowledge, subjective norms, perceived barriers, perceived benefits, and perceived vulnerability. The dependent variable is the intention of exclusive breastfeeding. Making criteria for each variable, namely, age ("younger" if 19 years old and "older" if >19 years old), level of lectures (semesters 1, 3, 5, and 7), knowledge [good if score median (10), less if score < median (10)], subjective norm [not supportive, if score < median (35), supports median (35)], perceived barrier [good if score < median (55); less if score $\geq$ median (55)], perceived benefits [good if score $\geq$ median (33) less if score < median (33)], vulnerability perception [good if score mean (37.77), less if score < mean (37.77)] exclusive breastfeeding intention [high if score $\geq$ mean (20), Low if score $<$ mean (20)]. The median is used as a categorical cutter for abnormal data, while the mean for normal data. The data were analyzed by univariate, bivariate (Chi-square Test), and multivariate analysis (Logistic Regression Test). Data analysis was performed with computer software with a significance of $\alpha=0.05$ (95\% confidence level).

\section{Results}

\section{Characteristics of respondents}

This study involved 187 active female students studying at the Public Health Study Program, Faculty of Health Sciences (FHS), Universitas Muhammadiyah 
Surakarta (UMS). The students are spread over several semesters (I, III, V, and VII) in the same large number, namely, 47 people. The distribution of student ages is between 17 and 24 years with the highest number at the age of 20 years $(28.3 \%)$ so that students who fall into the older age category (>19years) are larger (58.3\%). Students who have good knowledge about exclusive breastfeeding are more than those who have less knowledge, although the difference is not too big. Students who have subjective norms that support the practice of exclusive breastfeeding $(54.5 \%)$ are higher than those who do not (Table 1$)$.

Table 1: Description of student characteristics of public health study program FIK UMS, Surakarta, Indonesia

\begin{tabular}{lll}
\hline Variable & Frequency (n) & Percentage \\
\hline Age & 78 & \\
$\quad$ Younger & 109 & 41.7 \\
$\quad$ Older & & 58.3 \\
Min = 17 years old, Max = 24 years old & & \\
Lecture level & 47 & 25.1 \\
$\quad$ Semester 1 & 47 & 25.1 \\
$\quad$ Semester 3 & 47 & 25.1 \\
$\quad$ Semester 5 & 46 & 24.6 \\
$\quad$ Semester 7 & & \\
Knowledge & 81 & 43.3 \\
$\quad$ Low & 106 & 56.7 \\
$\quad$ High & & \\
Subjective norm & 85 & 45.5 \\
$\quad$ Not Support & 102 & 54.5 \\
$\quad$ Support & & 48.1 \\
Barrier perception & 90 & 51.9 \\
$\quad$ High & 97 & 32.1 \\
$\quad$ Low & & 67.9 \\
Benefit perception & 60 & 49.7 \\
$\quad$ Low & 127 & 50.3 \\
$\quad$ High & & 35.8 \\
Vulnerability perception & 93 & 64.2 \\
$\quad$ Low & 94 & \\
$\quad$ High & & \\
Exclusive breastfeeding intention & & \\
$\quad$ Weak & 120 & \\
Strong & &
\end{tabular}

Perceptions of low and high barriers to exclusive breastfeeding have almost the same percentage, namely, $51.9 \%$ and $48.1 \%$. While, the perception of the benefits of exclusive breastfeeding is dominated by a high perception (67.9\%). Perceptions of susceptibility to exclusive breastfeeding are low and high have the same amount. Most of the respondents had a strong exclusive breastfeeding intention (64.2\%) (Table 2).

Table 2: Results of analysis of relationship factors of age, knowledge, subjective norms, perceptions of barriers, perceptions of benefits, and perceptions of vulnerability with breastfeeding intentions by students of public health study Program FHS UMS, Surakarta (logistic regression test)

\begin{tabular}{|c|c|c|c|c|c|c|c|}
\hline \multirow[t]{3}{*}{ Variable } & \multicolumn{4}{|c|}{ Exclusive breastfeeding intentions } & \multirow{2}{*}{\multicolumn{2}{|c|}{ Total }} & \multirow[t]{3}{*}{$\mathrm{p}$-value } \\
\hline & \multicolumn{2}{|c|}{ Weak } & \multicolumn{2}{|c|}{ Strong } & & & \\
\hline & $\mathrm{n}$ & $\%$ & $\mathrm{n}$ & $\%$ & $\mathrm{n}$ & $\%$ & \\
\hline \multicolumn{8}{|l|}{ Age } \\
\hline Younger & 36 & 46.2 & 42 & 53.8 & 78 & 100 & \multirow[t]{2}{*}{0.006} \\
\hline Older & 31 & 28.4 & 78 & 71.6 & 109 & 100 & \\
\hline \multicolumn{8}{|l|}{ Knowledge } \\
\hline Low & 33 & 40.7 & 48 & 59.3 & 81 & 100 & \multirow[t]{2}{*}{0.58} \\
\hline High & 34 & 32.1 & 72 & 67.9 & 106 & 100 & \\
\hline \multicolumn{8}{|c|}{ Subjective norm } \\
\hline Not support & 44 & 51.8 & 41 & 48.2 & 85 & 100 & \multirow[t]{2}{*}{$<0.001$} \\
\hline Support & 23 & 22.5 & 79 & 77.5 & 102 & 100 & \\
\hline \multicolumn{8}{|c|}{ Barrier perception } \\
\hline High & 44 & 48.9 & 46 & 51.1 & 90 & 100 & \multirow[t]{2}{*}{$<0.001$} \\
\hline Low & 23 & 23.7 & 74 & 76.3 & 97 & 100 & \\
\hline \multicolumn{8}{|c|}{ Benefit perception } \\
\hline Low & 22 & 36.7 & 38 & 63.3 & 60 & 100 & \multirow[t]{2}{*}{0.128} \\
\hline High & 45 & 35.4 & 82 & 64.6 & 127 & 100 & \\
\hline \multicolumn{8}{|c|}{ Vulnerability perception } \\
\hline Low & 43 & 46.2 & 50 & 53.8 & 93 & 100 & \multirow[t]{2}{*}{0.002} \\
\hline High & 24 & 25.5 & 70 & 74.5 & 94 & 100 & \\
\hline
\end{tabular}

\section{intentions}

Factors related to exclusive breastfeeding

There are four of the six factors, namely, age $(p=0.006)$, subjective norms $(p<0.0001)$, perceived barriers $(p<0.0001)$, and perceived vulnerability $(p=0.002)$, significantly related with exclusive breastfeeding intentions. All of these variables were entered at an early stage and then several logistic regression models were built by looking at changes in adjusted Odd Ratio (OR), pseudo R2 values, Akaike Information Criterion (AIC), and Bayesian Information Criterion (BIC) values. Multicollinearity was found in the subjective norm variable with variables of age, perceived barriers, and perceived seriousness. The final model was selected based on the consideration of the highest pseudo R2 value and the goodness of fits test value. Based on the final model, the group of female students who had a supportive subjective norm tended to intention to breastfeed twice as strong as the female student who had a non-supportive subjective norm [OR $2.295 \% \mathrm{Cl}(1.072-4.603)]$. The quality of the model to predict breastfeeding intentions can be explained by the pseudo R2 value of 0.174 . This indicates that $17.4 \%$ of the variation in breastfeeding intentions can be explained by this model. Even so, the goodness of fit test analysis showed a $p=0.346$ (> 0.05 ) so it can be concluded that this model equation has a good calibration in providing correct predictions about breastfeeding intentions.

\section{Discussion}

The results showed that there was a significant relationship between the respondent's age and breastfeeding intentions. More mature respondents have a higher percentage of strong breastfeeding intentions than younger respondents. This is also in line with the research of Pentecost and Grassley (2014) which showed that younger breastfeeding mothers tend to wean their babies faster than adult mothers. They need social support, whether informational,

Table 3: Dominant factors related to breastfeeding intentions by students of public health study program FIK UMS, Surakarta

\begin{tabular}{|c|c|c|c|c|c|c|c|c|}
\hline \multirow[t]{3}{*}{ Variable } & \multicolumn{4}{|c|}{ First model } & \multicolumn{4}{|c|}{ Last model } \\
\hline & \multirow[t]{2}{*}{ OR } & \multicolumn{2}{|c|}{$95 \% \mathrm{Cl}$} & \multirow[t]{2}{*}{$p$-value } & \multirow[t]{2}{*}{ OR } & \multicolumn{2}{|c|}{$95 \% \mathrm{Cl}$} & \multirow[t]{2}{*}{$p$-value } \\
\hline & & Lower & Upper & & & Lower & Upper & \\
\hline \multicolumn{9}{|l|}{ Age } \\
\hline Younger ${ }^{\text {Ref }}$ & 1 & & & & - & & & \\
\hline Older & 1.606 & 0.570 & 4.520 & 0.370 & & & & \\
\hline \multicolumn{9}{|l|}{ Subjective norm } \\
\hline Not support ${ }^{\text {Ref }}$ & 1 & & & & 1 & & & \\
\hline Support & 2.222 & 1.072 & 4.603 & 0.032 & 2.222 & 1.072 & 4.603 & 0.032 \\
\hline \multicolumn{9}{|l|}{ Barrier perception } \\
\hline $\mathrm{High}^{\text {Ref }}$ & 1 & & & & - & & & \\
\hline Low & 1.816 & 0.874 & 3.772 & 0.110 & & & & \\
\hline \multicolumn{9}{|l|}{$\begin{array}{l}\text { Vulnerability } \\
\text { perception }\end{array}$} \\
\hline Low & 1 & & & & - & & & \\
\hline High & 1.593 & 0.797 & 3.184 & 0.187 & & & & \\
\hline
\end{tabular}


instrumental, emotional, or judgmental, during the breastfeeding process [8] (Table 3).

Support of health workers in the practice of breastfeeding is still less effective. This is by theassumption of young mothers who are breastfeeding that the attitude of health workers is not good in providing support. Even though they already have sufficient knowledge about breastfeeding, basic knowledge is still lacking so that they do early weaning for their babies [9]. Knowledge about breastfeeding is proven to increase the chances of successful breastfeeding and improve baby's health [10]. The results of this study indicate a non-significant relationship between knowledge and breastfeeding intentions. However, the group of respondents who have a strong breastfeeding intention has a higher percentage of respondents with good knowledge $(67.9 \%)$ than those with low knowledge (59.3\%).

Subjective norms become the dominant factor associated with exclusive breastfeeding intentions. Subjective norms are respondents' perceptions of breastfeeding practices that are influenced by social norms in their surrounding environment. The percentage of research respondents who have a strong breastfeeding intention with an assessment of subjective norms supporting $(77.5 \%)$ is greater than those who do not support (48.2\%). Mothers who have strong subjective norms can increase breastfeeding. This subjective norm usually comes from people who are considered important and imitated by respondents, such as family, community leaders, officials, and people closest to them [11]. There is an assumption that what influences breastfeeding attitudes is the experience of breastfeeding, not subjective norms. However, the grandmother's experience of breastfeeding mothers can predict subjective norms [12]. For example, the intervention of grandmother during the breastfeeding process can reduce the use of pacifiers in the first 6 months [13]. This subjective norm can be formed from the participation of grandmothers, husbands, and the closest people around breastfeeding mothers in supporting and promoting exclusive breastfeeding. This will have an impact on increasing positive attitudes and behaviors in breastfeeding [14], [15]. Therefore, since all of the respondents in this study were students who had no experience of breastfeeding, the role of this subjective norm became more dominant than other factors in shaping their intention to practice breastfeeding in the future. In addition, subjective norms about exclusive breastfeeding by their friends or other young women can influence female students' intentions to practice the same thing. Therefore, increase exclusive breastfeeding awareness among young women is needed to establish a collective norm of exclusive breastfeeding in society. This awarenessraising can be done using digital media and done by people who can make an impact on young women. As the results of research by Robinson et al. (2019) found that mentoring through Facebook can increase the mother's intention to breastfeed longer [16]. The previous study in Indonesia found that online campaign on Indonesian adolescent female was well accepted and motivated them to act the protective behavior. The health ministry needs to collaborate with influential person such as celebrity couple and other influential person to campaign about exclusive breastfeeding using social media that popular in Indonesian young women such as Instagram and Facebook [17].

This study shows that perceptions of breastfeeding barriers have a significant relationship with breastfeeding intentions. In the group of respondents who intend to give strong breast milk, a high percentage of respondents have a low perception of breastfeeding barriers. Perceptions of these barriers such as the need for breast milk for male infants are higher than for female infants, breastfeeding difficulties for working mothers, and lack of workplace support for expressing milk [18]. Other obstacles also arise from the health workers who do not provide support in providing information [19]. Even lactation consultants still face problems of professional management to overcome early initiation of breastfeeding [20]. Providing education can also influence perceptions of breastfeeding barriers due to better knowledge and a more positive attitude [21]. Respondents in the study were public health students who had sufficient knowledge about maternal and child health in several subjects they received. However, the fact is that there are still quite a several respondents who have a perception of barriers to breastfeeding.

Perceptions of vulnerability in the breastfeeding process have a significant relationship with breastfeeding intentions. In this study, most of the respondents have a perception of vulnerability tends to the mother. This perception of vulnerability if not breastfeeding the baby can be manifested in the form of actions to prevent, reduce, or control several things that are vulnerable to be faced when breastfeeding later. Preventive action against disease is believed to start from a person's perception of vulnerability and perception of benefit [22]. The problem of vulnerability in the breastfeeding process usually arises from the mother, baby, and lack of support from health workers. Especially for mothers who are breastfeeding for the first time, they tend to have low selfefficacy and breastfeeding knowledge [23]. Moreover, the respondents in this study will not only become prospective breastfeeding mothers but also prospective health workers who are tasked with providing education about breastfeeding to the public.

\section{Conclusion and Suggestion}

The majority of female students do have a strong intention to practice exclusive breastfeeding, but it is necessary to continue to improve their knowledge 
and skills about it until the time for breastfeeding arrives. This is due to the many external challenges that will be faced when mothers practice breastfeeding. Therefore, increase exclusive breastfeeding awareness among young women is needed to establish a collective norm of exclusive breastfeeding in society. In addition, further research needs to be done to confirm the results of this study in a larger setting. Hence, educational communication is needed to the environment around young women regarding the importance of exclusive breastfeeding so that the social environment can provide support to adolescents in the success of exclusive breastfeeding.

\section{References}

1. Kementerian Kesehatan RI. Profil Kesehatan Indonesia Tahun 2019. Jakarta, Indonesia: Kementerian Kesehatan RI; 2020. https://doi.org/10.33560/jmiki.v8i1.257

2. Agushybana F, Siramaneerat I, Raksamat W, Siriphakhamongkhon S. Population-based survey of exclusive breastfeeding in Indonesia: A secondary analysis. Pac Rim Int J Nurs Res. 2018;22(1):6-17.

3. Frota D, Marcopito L. Breastfeeding among teenage and adult mothers in Montes Claros MG Brazil. J Public Health. 2017;38(1):85-92.

4. Kanhadilok S, McCain NL, McGrath JM, Jallo N, Price SK, Chiaranai C. Factors associated with exclusive breastfeeding through four weeks postpartum in thai adolescent mothers. J Perinat Educ. 2016;25(3):150-61. https://doi. org/10.1891/1058-1243.25.3.150

PMid:30538412

5. Zakar R, Zakar MZ, Zaheer L, Fischer F. Exploring parental perceptions and knowledge regarding breastfeeding practices in Rajanpur, Punjab Province, Pakistan. Int Breastfeed J. 2018;13:24. https://doi.org/10.1186/s13006-018-0171-z PMid:29988704

6. Sukowati S, Shinta S. Peran tenaga kesehatan masyarakat dalam mengubah perilaku masyarakat menuju hidup bersih dan sehat. Med Health Res Dev. 2012;13(2):31-7. https://doi. org/10.31219/osf.io/92kfb

7. Sulaeman ES, Murti B, Setyawan H, Rinawati S. Exclusive breastfeeding behavior model in rural central Java, Indonesia: The application of theory of planned behavior. Glob J Health Sci. 2018;10(10):35. https://doi.org/10.5539/gjhs.v10n10p35

8. PentecostR, Grassley JS. Adolescents' needs for nurses' support when initiating breastfeeding. J Hum Lact. 2014;30(2):224-8. https://doi.org/10.1177/0890334413510358 PMid:24194610

9. Jamie K, O'Neill R, Bows $H$, Hackshaw-McGeagh $L$. Healthcare practitioner relationships, cultural health capital and breastfeeding support for adolescent mothers. Health Educ J. 2020;79(6):901-13. https://doi.org/10.1177/0017896920915945

10. Handayani L, Dewi MK, Munira L. Barrier and facilitator on breastfeeding education and promotion: A literature review. Int J Public Health Sci. 2020;9(4):320-6. https://doi.org/10.11591/ ijphs.v9i4.20495

11. Atika $Z$, Salimo H, Dewi YL. Multilevel analysis on the determinants of exclusive breastfeeding at gunung anyar community health center, Surabaya, Indonesia. J Matern
Child Health. 2018;3(3):76-183. https://doi.org/10.26911/ thejmch.2018.03.03.02

12. Bartle NC, Harvey K. Explaining infant feeding: The role of previous personal and vicarious experience on attitudes, subjective norms, self-efficacy, and breastfeeding outcomes. $\mathrm{Br} \mathrm{J}$ Health Psychol. 2017;22(4):763-85. https://doi.org/10.1111/bjhp.12254 PMid:28646537

13. Muelbert M, Giugliani ER. Factors associated with the maintenance of breastfeeding for 6,12 , and 24 months in adolescent mothers. BMC Public Health. 2018;18(1):675. https://doi.org/10.1186/s12889-018-5585-4 PMid:29855364

14. Rostamkhan S, Lakeh NM, Asiri S, Leili EK. Breastfeeding up to two years of age and its' associated factors based on behaviors, Attitudes, subjective norms, and enabling factors (BASNEF) model. J Holist Nurs Midwifery. 2020;30(1):9-16. https://doi. org/10.32598/jhnm.30.1.2

15. Wallenborn J, Ihongbe T, Rozario S, Masho S. Knowledge of breastfeeding recommendations and breastfeeding duration: A survival analysis on infant feeding practices II. Breastfeed Med. 2017;12:156-62. https://doi.org/10.1089/bfm.2016.0170 PMid:28394658

16. RobinsonA, Lauckner C, Davis M, Hall J, Anderson AK. Facebook supportfor breastfeeding mothers: Acomparison to offline support and associations with breastfeeding outcomes. Digit Health. 2019;5:1-12. https://doi.org/10.1177/2055207619853397 PMid:31218076

17. Januraga PP, Izwardi D, Crosita Y, Indrayathi PA, Kurniasari E, SutrisnaA, et al. Qualitative evaluation of a social media campaign to improve healthy food habits among urban adolescent females in Indonesia Public Health Nutr. 2021;24(S2):s98-107. https:// doi.org/10.1017/s1368980020002992 PMid: 32907648

18. Thepha T, Marais D, Bell J, Muangpin S. Perceptions of northeast Thai breastfeeding mothers regarding facilitators and barriers to six-month exclusive breastfeeding: Focus group discussions. Int Breastfeed J. 2018;13:14. https://doi. org/10.1186/s13006-018-0148-y PMid:29632549

19. Pemo K, Phillips D, Hutchinson AM. Midwives' perceptions of barriers to exclusive breastfeeding in Bhutan: A qualitative study. Women Birth. 2020;33(4):e377-84. https://doi.org/10.1016/j. wombi.2019.07.003

PMid:31337586

20. Anstey EH, Coulter M, Jevitt CM, Perrin KM, Dabrow S, Klasko- Foster LB, et al. Lactation consultants' perceived barriers to providing professional breastfeeding support. J Hum Lact. 2018;34(1):51-67. https://doi.org/10.1177/0890334417726305 PMid:28820951

21. Iliadou M, Lykeridou K, Prezerakos P, Swift EM, Tziaferi SG Measuring the effectiveness of a midwife-led education programme in terms of breastfeeding knowledge and self- efficacy, Attitudes towards breastfeeding, and perceived barriers of breastfeeding among pregnant women. Mater Sociomed. 2018;30(4):240-5. https://doi.org/10.5455/ msm.2018.30.240-245

PMid:30936785

22. Conner M. Cognitive determinants of health bevior. In: Handbook of Behavioral Medicine. Leeds, UK: Springer; 2010. p. 19-30.

23. Leurer MD, Petrucka $P$, Msafiri M. Maternal perceptions of breastfeeding and infant nutrition among a select group of Maasai women. BMC Pregnancy Childbirth. 2019;19(1):8. https://doi.org/10.1186/s12884-018-2165-7

PMid:30616549 